\section{Clouds and Connections}

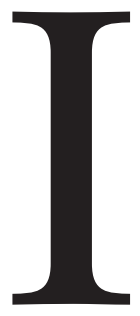

t's easy to be cynical about new computer-industry buzzwords, which are more often manufactured by corporate marketing departments than coined by those innovating in the trenches. So when we started hearing companies ranging from IBM to Amazon publicly touting their "cloud computing" initiatives, we wondered if it signified a real trend or a sales pitch-and whether these companies even had the same types of programs and technologies in mind when they used this relatively new phrase. So we dispatched intrepid reporter Aaron Weiss to investigate.

In his cover story, "Computing in the Clouds," Weiss writes that while cloud computing does take on a variety of specific meanings, the phrase is useful to describe a series of related trends that shift computing's center of power from the processor to the network, and draw on a variety of technologies to achieve that end. The resulting efficiencies will one day be seen as a real boon for business-and it can't be bad for all our beloved mobile devices, either. Why not be able to access whatever computing power you happen to need that morning while commuting to work?

Laurie Rowell's feature on wireless mesh networks, "Wired No More," dovetails nicely with the cover story. If processing and other functions migrate fully to the Web, fast and inexpensive broadband access will become crucial. Wireless mesh networks may fit the bill, especially with their extremely low power consumption-imagine broadband access in the U.S. powered exclusively by solar panelsand ease of set-up. The biggest obstacle to low-cost broadband access via wireless mesh networks appears to be today's giant cable and phone companies, who don't want their old business models disrupted and employ armies of lobbyists to keep things as they are.

Can our leaders find the political will to move us into the future? Election year is just around the corner.

Ken Korman,

Executive Editor
netWorker

is a quarterly publication of AcM,

The Association for Computing Machinery

PUblications office: ACM, 2 Penn Plaza, Suite 701, New York, New York 10121-0701, + 1-212-869-7440,

FAX: + 1-212-869-0481

Group Puublisher: Scott Delman

Executive Editor: Ken Korman Managing Editor: Denise Doig Art Director: Caren Rosenblatt Production Manager: Lynn D'AddesioKraus

Account Executive: William Kooney

Contributing Editors:

Put IngitTogether Win Treese (treese@acm.org)

$\mathrm{N}$ et News: Alan Zeichick

(zeichick@acm.org)

Books Michele Tepper

(mtepper@panix.com)

Editorial advisory board:

Grady Booch

Bran Ferran

Jim Gemmell

David S. Isenberg

Jakob Nielsen

Donald A. Norman

Daniel Rosenberg

ACM Advertising Department

2 Penn Plaza, Suite 701

New York, NY 10121-0701

(212) 869-7440; Fax (212) 869-0481

Account Executive:

William R. Kooney

email: acm-advertising@acm.org

networker (ISSN 1091-3556) is published four times a year in March, June, September, and December by the Association for Computing Machinery, Inc., 2 Penn Plaza, Suite 701, New York, NY 10121-0701.

Periodical class postage paid at New York, NY 1000l, and at additional mailing offices. Printed in the U.S.A.

POSTMASTER: Send address changes to netWorker, ACM, 2 Penn Plaza, Suite 701, New York, NY 10121-0701. 